\title{
"Things I Can Remember about My Life": Autobiography and Fatherhood in Victorian Britain
}

\section{Emma Griffin}

\begin{abstract}
It is now nearly forty years since John Burnett, David Vincent, and David Mayall compiled their invaluable and much-used three-volume finding aid, The Autobiography of the Working Class: An Annotated, Critical Bibliography (1984-1989), and established working-class autobiography as an important documentary source for exploring the lives of the working poor. Life writing now forms the basis of historical research into areas such as the emotions and domestic life that had hardly been imagined at the time that the annotated bibliography was produced. Yet as research into workingclass autobiography has extended into new domains of enquiry, there has been less innovation in methodology. Historians typically use autobiographical material to pursue deep-reading strategies and unpack the meaning, experience, and identity of individual writers rather than generalize about working-class life more broadly. In this article I offer an alternative strategy: to take the autobiographical corpus and read it at scale in order to better understand fatherhood in Victorian Britain. Through a combination of intensive and extensive reading, I demonstrate that many working-class men failed to live up to expectations as breadwinners, and I explore the ramifications of that failure for the women and children with whom they lived.
\end{abstract}

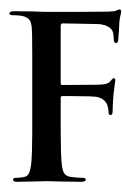

our decades ago, John Burnett, David Vincent, and David Mayall secured funding from the Leverhulme Trust for a project to identify and document Britain's scattered collection of working-class autobiographies and demonstrate its value as historical source material. With two edited volumes of working-class autobiography, ${ }^{1}$ scholarly articles, ${ }^{2}$ and one monograph, ${ }^{3}$ the team demonstrated the existence of a large body of little-known working-class

Emma Griffin is professor of modern British history at the University of East Anglia. She is grateful to the British Academy (MD140027) and the Arts and Humanities Research Council (AH/I00033X/1) for helping to fund this research and to audiences at seminars at Oregon State University and the universities of Bath, Cambridge, Lincoln, Winchester, and Glasgow, and to the journal's editors and reviewers for their feedback on this article. The quotation in the title is taken from Alice Maude Chadwick, "Maude's Memoirs," 1, Guildford Museum, Guildford. Please direct any correspondence to E.Griffin@ uea.ac.uk.

${ }^{1}$ David Vincent, Testaments of Radicalism: Memoirs of Working Class Politicians, 1790-1885 (London, 1977); John Burnett, ed., Useful Toil: Autobiographies of Working People from the 1820s to the 1920s (London, 1974); John Burnett, ed., Destiny Obscure: Autobiographies of Childhood, Education and Family from the 1820s to the 1920s (London, 1982).

${ }^{2}$ David Vincent, "Love and Death and the Nineteenth-Century Working Class," Social History 5, no. 2 (1980): 223-47; John Burnett, "Autobiographies of Childhood: The Experience of Education," History Today 32, no. 9 (1982): 8-13; David Mayall, "Rescued from the Shadows of Exile: Nellie Driver, Autobiography and the British Union of Fascists," Immigrants and Minorities 8, no. 1-2 (1989): 19-39.

${ }^{3}$ David Vincent, Bread, Knowledge and Freedom: A Study of Nineteenth-Century Working Class Autobiography (London, 1981). 
autobiography and illustrated how it might be analyzed to shed light on the past. Perhaps most significantly, they also solicited, collected, and archived new and unknown specimens of working-class life writing (now housed in the special collections of the Brunel University library) and compiled their invaluable and much-used finding aid, The Autobiography of the Working Class: An Annotated, Critical Bibliography, so that others might navigate this material to pursue their own research agendas. ${ }^{4}$

As with all endeavors of cataloguing and archiving, Burnett and his team brought to bear their own assumptions about what made working-class autobiography important and useful. The original researchers prized the autobiographies primarily for their unparalleled insights into the male worlds of work and politics, and they recorded these details with particular care in the annotated bibliography. Thus Robert Lowery's comprehensive account of his engagement in early nineteenthcentury radical politics is described as "important" and "invaluable," while the autobiography of poor Tabitha John, a Llanelli housewife, that is largely "concerned with personal affairs (home; family; courtship)," is dismissed as "anecdotal" and "rather desultory." The autobiography of the housewife Martha Martin is deemed to be "of little historical value." 5 Yet whatever the compilers' own views of the autobiographical material they uncovered, they included it all in their bibliography, thereby throwing open the door for the next generation of historians to find and interrogate any part of the corpus in whatever way they chose.

Their intervention could hardly have been more timely. With much of this work appearing in the heyday of the social history movement, it found a large, interested audience. The annotated bibliography quickly became a point of reference, and working-class autobiography was seamlessly absorbed into a new wave of studies exploring the lives of the working poor. Large literatures on working-class politics began to appear, ${ }^{6}$ as did other studies on education, literacy, and the intellectual life of working men. ${ }^{7}$ In a similar way, the bibliography facilitated and enriched research into the history of working people ${ }^{8}$ and those who were out of work altogether. ${ }^{9}$

Furthermore, the original team's act of laying bare the existence of the autobiographical archive and the creation of their finding aid enabled scholars to explore and engage new topics and old, and it soon fostered research that lay beyond the

\footnotetext{
${ }^{4}$ John Burnett, David Vincent, and David Mayall, eds., The Autobiography of the Working Class: An Annotated, Critical Bibliography, 3 vols. (New York, 1984-1989).

${ }^{5}$ Burnett, Vincent, and Mayall, Autobiography of the Working Class, 1:204, 174, 222.

${ }^{6}$ Martin Hewitt, "Radicalism and the Victorian Working Class: The Case of Samuel Bamford," Historical Journal 34, no. 4 (1991): 873-92; Paul Readman, "The Conservative Party, Patriotism, and British Politics: The Case of the General Election of 1900," Journal of British Studies 40, no. 1 (2001): 10745; Marc Brodie, The Politics of the Poor: The East End of London, 1885-1914 (Oxford, 2004).

${ }^{7}$ Regenia Gagnier, Subjectivities: A History of Self-Representation in Britain, 1832-1920 (Oxford, 1991); Jonathan Rose, The Intellectual Life of the British Working Classes (New Haven, 2001); Julie F. Codell, "Alexander Somerville's Rise from Serfdom: Working-Class Self-Fashioning through Journalism, Autobiography, and Political Economy," in The Working-Class Intellectual in Eighteenth-and Nineteenth-Century Britain, ed. Aruna Krishnamurthy (Farnham, 2009), 195-218.

${ }^{8}$ Neil Ramsey, The Military Memoir and Romantic Literary Culture, 1780-1835 (Farnham, 2011); Keith Gildart, "Mining Memories: Reading Coalfield Autobiographies," Labor History 50, no. 2 (2009): 13961.

9 Sally Alexander, "Men's Fears and Women's Work: Responses to Unemployment in London between the Wars," Gender and History 12, no. 2 (2000): 401-25.
} 
parameters they had initially conceived. Thanks in no small part to the influence of women's and feminist history, the 1990s and 2000s saw a number of studies that sought to expand the new field to include female experiences and to situate women as historical agents in their own right-in politics, ${ }^{10}$ as writers, ${ }^{11}$ and as workers. ${ }^{12}$ But perhaps the most important legacy of feminist historians has been to force a reevaluation of the historical significance of that "desultory" business of domestic life. ${ }^{13}$ In consequence, working-class autobiography has been exploited to probe such subjects as food and consumption, ${ }^{14}$ clothing, ${ }^{15}$ homes, ${ }^{16}$ childhood, ${ }^{17}$ and intimate family relationships. ${ }^{18}$ Indeed, the staking out of domestic life and (more recently) the emotions as subjects worthy of study has helped to consolidate and elevate the status of autobiographies as primary source material. After all, it is hard to envisage any other set of records that could shed light on the private spheres of home and emotion. The team hoped their work would "do much to rescue autobiography from its status as a purely marginal category of source material," and four decades later it seems safe to conclude that it certainly has. ${ }^{19}$

${ }^{10}$ Andrew August, "A Culture of Consolation? Rethinking Politics in Working-Class London, 18701914," Historical Research 74, no. 184 (2001): 193-219; Carolyn Tilghman, "Autobiography as Dissidence: Subjectivity, Sexuality, and the Women's Co-operative Guild," Biography 26, no. 4 (2003): 583606.

${ }^{11}$ Tess Cosslett, Celia Lury, and Penny Summerfield, eds., Feminism and Autobiography: Texts, Theories, Methods (London, 2000); Susan Zlotnick, Women, Writing, and the Industrial Revolution (Baltimore, 2001); Kelly Mays, "Domestic Spaces, Readerly Acts: Reading(,) Gender, and Class in Working-Class Autobiography," Nineteenth-Century Contexts 30, no. 4 (2008): 343-68; Florence S. Boos, Memoirs of Victorian Working-Class Women: The Hard Way Up (Basingstoke, 2017).

12 Jane McDermid, “The Making of a 'Domestic' Life: Memories of a Working Woman,” Labour History Review 73, no 3 (2008): 253-68; Lucy Delap, Knowing Their Place: Domestic Service in Twentieth-Century Britain (Oxford, 2011).

${ }^{13}$ Joanna Bourke, "Housewifery in Working-Class England, 1860-1914," Past and Present, no. 143 (1994): 167-97. See also Melanie Tebbutt, Women's Talk? A Social History of "Gossip" in Working-Class Neighbourhoods, 1880-1960 (Brookfield, 1995).

${ }^{14}$ Anna Davin, "Loaves and Fishes: Food in Poor Households in Late Nineteenth-Century London," History Workshop Journal, no. 41 (1996): 167-92; Margaret Willes, The Gardens of the British Working Class (New Haven, 2014).

${ }^{15}$ Laura Ugolini, "Autobiographies and Menswear Consumption in Britain, c. 1880-1939," Textile History 40, no. 2 (2009): 202-11; Fanny Louvier, "Beyond the Black and White: Female Domestic Servants, Dress and Identity in France and Britain, 1900-1939," Cultural and Social History 16, no. 5 (2019): $581-602$.

${ }^{16}$ Megan Doolittle, “Time, Space, and Memories: The Father's Chair and Grandfather Clocks in Victorian Working-Class Domestic Lives," Home Cultures 8, no. 3 (2011): 245-64; Julie-Marie Strange, "Fatherhood, Furniture and the Inter-personal Dynamics of Working-Class Homes, c. 1870-1914," Urban History 40, no. 2 (2013): 271-86.

${ }^{17}$ Jacob Middleton, "The Cock of the School: A Cultural History of Playground Violence on Britain, 1880-1940," Journal of British Studies 52, no. 4 (2013): 887-907.

${ }^{18}$ Ellen Ross, Love and Toil: Motherhood in Outcast London, 1870-1918 (New York, 1993), esp. 69-78; Lynn Abrams, "“There Was Nobody Like My Daddy': Fathers, the Family and the Marginalisation of Men in Modern Scotland," Scottish Historical Review 78, no. 206 (1999): 219-42; Julie-Marie Strange, Fatherhood and the British Working Class, 1865-1914 (Cambridge, 2015); Helen Rogers, "First in the House': Daughters on Working-Class Fathers and Fatherhood," in Gender and Fatherhood in the Nineteenth Century, ed. Trev Lynn Broughton and Helen Rogers (Basingstoke, 2007), 126-37.

19 Burnett, Vincent, and Mayall, Autobiography of the Working Class, xix. 
Yet as research into working-class autobiography has extended into new domains of enquiry, there has been less innovation in methodology. Of course autobiographies are inherently subjective in nature. From the outset, David Vincent was clear about the limitations this posed upon scholarly use of the material. He strongly counselled against trying to "aggregate certain aspects of the autobiographies" in order to generalize about working-class life. The writers, he warned, were not "a statistically accurate sample of the working class," and "no truths, either general or in particular, can be deduced by adding up their contents and dividing by the total number." 20 This stricture has proved to be one with a very long life. It is widely accepted that autobiography involves the rewriting of earlier lived events, raising problems of memory and the retrospective imposition of meaning and order on earlier experiences. $^{21}$

But rather than abandon the enterprise in the face of these drawbacks, this research has instead sought to position the subjectivity of the author as the focus of interest rather than a problem that needs to be navigated. This maneuver has enabled research into working-class life to proceed, but it has also imposed some hefty restrictions on the ways that autobiographies are used. In the large literature of the past twenty years, there has been an unmistakable turn away from generalizing narratives toward a focus on the particular. Research has tended to converge on questions of personal identity ${ }^{22}$ and lived experience. ${ }^{23}$ Attention is focused on how the records were created and what this tells us about the individuals who penned them, rather than on the world in which they held those pens, a method that is sometimes described as one of "close reading." 24 It is an approach summarized by Claire Lynch's statement, "The intention is to excavate not what an autobiography can tell us about bricklaying or train driving but rather what it meant to that individual to be a bricklayer or a train driver in the context of his own life."25

Undoubtedly the search for meaning, experience, and identity has been a fruitful scholarly endeavor. Autobiographical writers did situate themselves in the world, and probing the documents they created in order to understand that process of self-situation is a legitimate and worthwhile exercise. But might we be missing something by confining our analyses in this way? After all, the autobiographers were not only seeking to give meaning to their own experience. They were also seeking to inform readers of a world that had passed. Their writing was teeming with information about the society they lived in, and about how they and others fitted in to it. They described families, homes, streets, schools, workplaces, and much else besides, not only to make sense of their own place in these contexts but also to memorialize a world that was fast disappearing. Might it be possible to supplement the dominant mode of research on life writing in which the goal is to get behind the

${ }^{20}$ Vincent, Bread, Knowledge and Freedom, 10.

${ }^{21}$ This is the approach of the sources listed above in notes 6-8 and below in notes 22-25.

${ }^{22}$ Louvier, "Beyond the Black and White"; Ugolini, "Autobiographies and Menswear Consumption in Britain”; McDermid, “The Making of a 'Domestic' Life,” 255; Gildart, "Mining Memories,” 139-61.

${ }^{23}$ Doolittle, "Time, Space, and Memories," 249; Claire Lynch, "Unlike Actors, Politicians or Eminent Military Men': The Meaning of Hard Work in Working Class Autobiography," a/b: Auto/Biography Studies 25, no. 2 (2010): 186-202, at 187, 200.

${ }^{24}$ McDermid, "The Making of a 'Domestic' Life," 255; Gildart, "Mining Memories," 154.

${ }^{25}$ Lynch, "Unlike Actors, Politicians or Eminent Military Men," 187-88. 
document to the individual who created it with one that seeks to read forward and out from the documents into the world in which their creators lived?

Helen Rogers and Emily Cuming have helpfully suggested that we could move forward research on life writing with the concept of "distant reading." That is, that in addition to the close reading of particular texts, we can also take the autobiographical corpus as a whole in order to "to identify patterns and trends in authorship and cultural expression." 26 I agree and go further. I believe that we can work with the autobiographies at scale, but not simply in order to discern patterns of authorship. In addition, we can and should look for ways of linking autobiographical texts to the exterior world and use them to shed light on the larger social, cultural, and economic forces that shaped their authors' lives.

My focus in this article is the working-class family, in particular questions of fatherhood and provision. My approach has been to proceed on a large canvas, working systematically through the bibliography that Burnett and his team compiled, and my aim is to explore connections between the individual writer and the material world they inhabited. My starting point was the following question: How well did Victorian fathers provide for their families? The question should not be understood as asking how much they provided. Working men possessed different levels of skill and could thus command widely differing rates of pay. Inevitably, those situated at the lower end of the scale were able to hand over far less than those at the upper end. What I am asking is this: Given each individual man's skills and his capacity for earning, how well did he actually provide for his family? As can be seen, my question is not what the act of provision meant to the man who did (or did not) provide for his family, nor what it meant to the child who would later describe it in his or her autobiography. My interest is more prosaic: it is about money, who earned it, who spent it, and how it was shared between earning and nonearning members of the family. In describing the results of my study, I hope to shift attention away from perceptions and experiences of fatherhood and instead shed light on how well the breadwinner family model operated within the working-class autobiographers' families.

The wider significance of the question can be illustrated by the example of the actor Charlie Chaplin. ${ }^{27}$ As a successful music-hall singer, his father, Charles Chaplin Sr., could command a high weekly income-up to forty pounds a week during his heyday, his son later noted with a palpable sense of pride. But he only ever gave a tiny fraction of that sum to Charlie's mother for their upkeep, ten shillings a week, little more than 1 percent of his maximum earnings. Moreover, although he could on occasion bring in very high earnings, he did not maintain these through the course of Charlie's childhood. The trouble, as his son recalled, "was that he drank too much." As he descended into alcoholism, his earnings dwindled, but his personal claim on them increased. His child maintenance dried up altogether. The adult Charlie Chaplin had complex and ambivalent feelings toward his father, but his verdict on the material provision he had received from him was neither complex nor ambivalent: Charles Sr. was simply a poor provider for his family. Nor should we imagine that what is simple must also be unimportant. Charlie's childhood was

\footnotetext{
${ }^{26}$ Helen Rogers and Emily Cuming, "Revealing Fragments: Close and Distant Reading of WorkingClass Autobiography," Family and Community History 21, no. 3 (2018): 180-201, at 191.

${ }_{27}$ Charles Spencer Chaplin, My Autobiography (London, 1964), 15-20, at 15.
} 
blighted by crushing poverty, heartbreaking separations from his mother, and institutionalization. It is not only legitimate to shift the focus away from the meaning of fatherhood: it is both possible and worthwhile to trace a line between Mr. Chaplin's performance of fatherhood, and the material outcomes for his wife and child.

Using the Autobiography of the Working Class and other resources, I first identified 662 writers born between 1840 and 1905, who therefore described childhoods that spanned the Victorian and Edwardian eras. ${ }^{28}$ I consulted each account and interrogated the nature of the father's breadwinning. Of course, as mortality was high in Victorian Britain, not all writers had a living father. Around 12 percent had lost their father before the age of sixteen, and I removed all these from the sample, reducing the collection of autobiographies to 577. I then read through all the life histories to categorize their fathers according to how well they provided for their children. Although a few writers were unclear about this element of their family life or provided accounts that were inconsistent or otherwise difficult to interpret, most of them clearly described this aspect of their family life. Indeed, it was no doubt owing to the huge importance of a father's wage-earning to the well-being of a working-class family that the quality of the father's breadwinning was relatively straightforward to establish in the majority of autobiographies.

The autobiographies indicate that provision was the cornerstone of working-class conceptions of fatherhood, and writers repeatedly used this as the benchmark for evaluating their fathers. ${ }^{29}$ And of course, many of the autobiographers recalled fathers who had successfully provided for their families. Edward Robinson's father, for example, was not a high earner, but he was a good provider. Although his earnings as a cabdriver were uncertain and sometimes small, on a daily basis he handed every penny he earned over to his wife, who set about transforming the money into food. On a bad day, Edward's meal might consist of nothing more than a half-penny bloater with bread and butter, but anything more provided the family with "a good dinner." It helped that Edward's father did not drink or smoke-his life "was just work and sleep." 30 Mr. Robinson's behavior did not provide his family with fine living; his earnings were simply too low for that. But it did ensure that young Edward enjoyed a degree of comfort and security throughout his early years.

Mr. Robinson was certainly not alone in performing his breadwinning effectively and with good grace. Gratitude to hardworking fathers- to men like John Blake's father for their years of "self-denial, devotion and constant effort"31_runs throughout the autobiographical literature. Harry Gosling considered that his father had

\footnotetext{
${ }^{28}$ I discuss these autobiographies more fully in Emma Griffin, Bread Winner: An Intimate History of the Victorian Economy (New Haven, 2020).

${ }^{29}$ For the connection between providing and fatherhood, see Strange, Fatherhood and the British Working Class, 21-48; Bourke, "Housewifery in Working-Class England," 167-97; Ross, Love and Toil.

${ }^{30}$ Edward Robinson, "I Remember," Burnett Archive of Working-Class Autobiography, Brunel University, London, ref. no. 1:593, p. 7. (This repository is hereafter abbreviated as BAWCA.)

${ }^{31}$ John Blake, Memories of Old Poplar (London, 1977), 8.
} 
been "a model father" who had done "everything in his power for all of us." 32 A steady wage formed the bedrock of a family's well-being, and the father who had labored hard to earn it was fondly remembered. John Clyne's father was a "fine worker." He took no holidays and used his earnings to ensure his children got the schooling that he had missed. ${ }^{33}$ Henry Turner's father had regular work as a lamplighter and also earned a little extra by spending his spare time cleaning windows. ${ }^{34}$ Like Edward Robinson's father, he hardly drank, and his one indulgence was the occasional smoke: roll-ups as thin as matchsticks. ${ }^{35}$ James Brady's father worked a series of second jobs around his main occupation as a clog-iron maker and spent what he earned on holidays for his family. ${ }^{36}$

Although the breadwinner model worked well in some families, it is important to ask how common such outcomes were. Of 577 autobiographies, just over 211 writers—or 37 percent-provided evidence that their father had been a reliable wage earner who dutifully shared his earnings with his family. Good breadwinners were not necessarily those who earned the most: actual earnings could be, and often were, small. Instead, good providers (in the eyes of the autobiographers) were those who worked steadily and shared their earnings generously with their families. No matter the size of the pay packet, most of the autobiographers believed that a steadily working father had done enough to provide his children with a reasonably comfortable and stable start in life. Yet these 211 writers constitute less than half of all the autobiographers, so the account of fatherhood cannot be closed on the comforting image of men working second jobs in order to purchase little luxuries for their families. Although some fathers both worked hard and shared their earnings with their families, a great many apparently did not. What other models of paternity are described in the autobiographies?

Breadwinning and provision were highly valued among working-class writers, yet time and time again writers make clear that this was not something that their own fathers had been able to achieve. To start with, there was the perennial problem of unemployment. Margaret Powell's father was a painter and decorator-a "sort of general odd-job man." But, as she explained, most people did not want the bother of home improvements during the coldest months, so every winter he struggled to find work. ${ }^{37}$ In his daughter's eyes, his struggle to provide for his family did not diminish his worth as a father. He delighted in buying the children a comic and a bag of sweets on Sundays, and his family knew "he did the best he could." But his unemployment did, of course, have a very significant effect on his family's quality of life. Among Powell's earliest recollections was the realization that "other children seemed to be better off than we were." That poverty of her upbringing, she later concluded, might be sociologically interesting, but experiencing it "was just plain foul." 38

More occasionally, men were afflicted with such bad health they were unable to work at all. Arthur Collinson's father, for example, had worked as a coach-builder

32 Harry Gosling, Up and Down Stream (London, 1927), 7.

${ }^{33}$ J. R. Clynes, Memoirs, 1869-1924 (London, 1937), 27-28.

34 "Henry Turner," in The Island: The Life and Death of an East London Community, 1870-1970, ed.

Hackney Workers' Educational Association (London, 1979), 19-20.

${ }^{35}$ Robinson, "I Remember."

36 "James Brady, "A Long, Long Trail A-winding," in Burnett, Destiny Obscure, 316-22.

${ }^{37}$ Margaret Powell, Below Stairs (London, 1968), 5.

${ }^{38}$ Powell, Below Stairs, 112. 
until Arthur was five. At that point he lost his sight, and his family lost its position among the "great mass of poor" and joined the "under privileged." 39 Cases such as these exposed the weakness of the breadwinner model. When breadwinners were out of work, whether through unemployment or ill-health, men were left with nothing beyond what little insurance they may have been able to take out against such calamities. Inevitably, insurance was the preserve of the more skilled workers: the great mass of the workforce were never in a position to insure themselves against unemployment. And even for these privileged few, insurance was quickly exhausted, leaving not just them but their entire families facing destitution.

Yet gesturing to unemployment and ill-health scarcely scratches the surface of the weaknesses of the breadwinner model. Alongside the relatively small number of men who were unable to earn a living for their families, a much larger number of men were able to provide, yet made choices that left their families with less than they might have had. Although fathers were supposed to be hardworking breadwinners, not all undertook this role with much relish. Joseph Wright's father simply did not enjoy hard, manual labor. He could earn a decent rate in the iron mines, but he much preferred leisure to work. If he worked steadily "for perhaps a fortnight he would take a holiday and spend what he had earned." 40 Jean Rennie also lamented that her father, "although a good workman, was not a steady one."4l Arthur Harding thought that the presence of his father had done very little to add to the well-being of his family. According to Harding, he was "a loafer" and "too lazy to earn a living." ${ }^{2}$ A small number of men simply refused to work, and the consequences for their families were serious. Mr. Wright's "happy-go-lucky temperament" reduced his family to destitution. Joseph, with his mother and his three siblings, spent his early childhood in the workhouse while his "happy-go-lucky" father followed his own inclinations on the outside. ${ }^{43}$

Unemployment, ill-health, or a simple disinclination to work could all leave families without a male wage for their sustenance. Yet among the autobiographers, the number of fathers who did not bring home a steady weekly wage was comparatively small. The autobiographers were far more likely to recall a father who earned a steady wage but failed to share it with their families than a father who did not work steadily. It was of course customary for men to keep a part of their wages as "pocket money," or to claim a greater share of the family's food owing to their central role in procuring it. It is difficult to get a sense of exactly what amount of pocket money was deemed reasonable, and it is worth pointing out that when earnings were low, even a small sum creamed off by the male head of household was to the detriment of everybody else's nutrition. ${ }^{44}$ But let us accept that a small amount of pocket money or dietary privilege was a widely accepted perquisite for a male wage earner. The problem

\footnotetext{
39 Arthur T. Collinson, "One Way Only: An Autobiography of an Old-Time Trade Unionist," BAWCA, ref. no. $3: 30$, p. 4.

${ }^{40}$ Elizabeth Mary Wright, The Life of Joseph Wright (Oxford, 1932), 26.

${ }^{41}$ Jean Rennie, Every Other Sunday (Bath, 1975), 12.

${ }^{42}$ Raphael Samuel, ed., East End Underworld: Chapters in the Life of Arthur Harding (London, 1981), 24, 29, see also 28-31, 64-65.

${ }^{43}$ Elizabeth Mary Wright, The Life of Joseph Wright (Oxford, 1932), 26.

44 This issue has been largely neglected since Laura Oren, "The Welfare of Women in Laboring Families: England, 1860-1950," Feminist Studies 1, nos. 3-4 (1973): 107-25; see also Ross, Love and Toil, 31-36, 76-78; Bourke, "Housewifery in Working-Class England," 181-82; Sébastien Rioux, "Capitalism and the
} 
nonetheless remained that wages were paid into the hands of the male worker, not his wife. The allocation of wages between male pocket money and female housekeeping money was thus a matter that could be decided by the male wage-earner alone, and the outcome of this imbalance for family finances is as predictable as it is obvious.

In the eyes of some autobiographers, their fathers had reserved for themselves more "pocket money" than seemed acceptable from the family perspective. Muriel Box's father earned a respectable two pounds a week but refused to hand it over to his wife for housekeeping, declaring "You can't draw blood out of a stone!" 45 The result was "daily bickerings over money which erupted into savage rows and, on very rare occasions, blows." 46 George Williams's father had a similar attitude toward his earnings. According to his Williams, his father "cherished one fixed idea about wages . . . he would never disclose the amount of his weekly pay-packet, not under duress or caress, not by wheedle or needle. Every week a certain sum was handed over, the rest a private matter." 47 There was a ritual in Leily Broomhill's household when her mother's housekeeping money ran low: "She used to say to us children, 'I'm going in the other room. Don't come in. I'm going to ask him if he'll let me have any money." The outcome of these attempts was always the same. She would return to the children and "shake her head. He never hit her, and they never quarreled, but he never gave her any money." 48 Albert Jasper's father was so determined to keep a chunk of his income for himself that he always slipped "his money bag under his side of the mattress" before falling asleep. To make certain that his wife could not put his money toward housekeeping, he occasionally slept with it in his sock. ${ }^{49}$

Men had a variety of motives for withholding part of their wages for themselves. A few were involved in worthy social or political enterprises. Robert Oakley, for example, fell in with the Methodists. He was not wasting his earnings in the pub, but he was still diverting money away from his family, and what was good for Oakley's spiritual needs was much less beneficial for his children's nutrition. His wife lamented his "going so much to chapel and taking the money away to give there that my children and I so badly wanted at home." $" 50$ As Mrs. Oakley was attempting to raise a family during the "hungry forties," the basis for her complaint was real indeed. John Allaway's father was a respectable supervisor for a metalworking business and involved in a number of mutual societies-grand master for the Order of Buffaloes and "chairman of this club and that." His son believed that his personal spending on these causes forced his mother to "pinch and scrape more than she need have done."51 Kate Taylor's father's hobbyhorse was the village

\footnotetext{
Production of Uneven Bodies: Women, Motherhood and Food Distribution in Britain c. 1850-1914,” Transactions of the Institute of British Geographers 40, no. 1 (2015): 1-13.

${ }^{45}$ Muriel Box, Odd Woman Out: An Autobiography (London, 1974), 16.

${ }^{46}$ Box, Odd Woman Out, 16.

${ }^{47}$ Emlyn Williams, George: An Early Autobiography (London, 1961), 16.

${ }^{48}$ Leily Broomhill, "In Memory of My Mum," in "Like It Was Yesterday": Childhood Memories, ed. Daphne Chamberlain (London, 1989), n.p.

${ }^{49}$ A. S. Jasper, A Hoxton Childhood (London, 1969), 40, 51.

${ }^{50}$ Elizabeth Oakley, "The Autobiography of Elizabeth Oakley, 1831-1900," Norfolk Record Society, no. 56 (1993): 113-50, at 143.

51 "John Allaway," in Breakthrough: Autobiographical Accounts of the Education of Some Socially Disadvantaged Children, ed. Ronald Goldman (London, 1968), 1-18, at 5-6.
} 
Salvation Army band. Despite the family's "poverty-stricken condition," he would invite his fellow bandsmen to dine on the Sunday meal his wife had prepared, leaving his hungry children to "scavenge for any crumbs they may have left." 52

In reality, though, most men who diverted their earnings away from their families were not putting it toward religious, political, or other worthy interests. They just liked to spend it on themselves. Vere Garratt could only marvel at his father's abiding passion for gambling on the horses. The sums he wasted were "incredible" for a man "with a large family and slender resources." 53 Joseph Sharpe's father was a miner and a "connoisseur of whippets and greyhounds." He had income sufficient to buy meat for his dogs, but not, unfortunately, for his children-his son recalled a scanty, vegetarian diet of "tea sops, oatmeal porridge and flour porridge." He ran "barefooted and barelegged" too. ${ }^{54}$ Nellie Hoare's father believed in "sharing" his wages with his wife. This meant keeping half of his earnings to himself and giving her the other half: "He used to spend his fifteen shillings on beer and tobacco and I remember he used to smoke a clay pipe.” Mother's fifteen shillings went on rent, food, and clothing for a family of ten. ${ }^{55}$

Most commonly of all, male wages were used to fund a drinking habit that had escalated out of control. Running like a thread through accounts of working-class family life is the father who earned a good wage but drank away most of what he earned. Alfred Coppard summed up the situation for many: his father, he wrote, was "something of a drinker, and so we were always shockingly poor." 56 Drinking was also the reason that Albert Jasper's father stuffed his money under the mattress or into his sock while he slept. Although Mr. Jasper "always had money" his son complained that his mother never had a full week's wages from him because "his main object in life was to be continually drunk." 57 In Bolton, Alice Foley's father worked only in "fits and starts" as his life was punctuated with bouts of heavy drinking that incapacitated him for work. Occasionally, "he disappeared for weeks, leaving his whereabouts unknown, then just as suddenly he turned up penniless and unkempt." During such interludes, his wife took on the role of breadwinner, though her meager earnings from the washtub were obviously no substitute for her husband's wage. And the loss of earnings was not the least of it. Sid Foley's drinking sprees not only impoverished his family but also put it at risk of unpredictable eruptions of violence. When recovering from a boozing bout, "his temper was most vicious and unpredictable," and Alice Foley had a large stock of memories about the outbursts she witnessed as a child. ${ }^{58}$

Clearly, the presence of a father, even one who was in work, provided no guarantee that his children would see much of his wages. But for some families, unreliable provision was the prelude to something worse: desertion. The fathers of Joseph Wright,

52 Kate Taylor, unpublished autobiography, in Burnett, Destiny Obscure, 301-9, at 305.

${ }^{53}$ Vere W. Garratt, A Man in the Street (London, 1939), 4-6.

${ }^{54}$ Nellie Connole, Dark at Seven: The Life of a Derbyshire Miner: Being an Account of His Life as Told by Joseph Sharpe of Coal Aston in the County of Derbyshire, 1859-1936 (York, 1988), 1.

${ }_{55}$ Nellie Hoare, A Winton Story (Bournemouth, 1982), 3.

${ }^{56}$ A. E. Coppard, It's Me, O Lord! An Abstract and Brief Chronicle of Some of the Life with Some of the Opinions of A. E. Coppard, Written by Himself (London, 1957), 14.

${ }^{57}$ Jasper, Hoxton Childhood, 9.

${ }^{58}$ Alice Foley, A Bolton Childhood (Manchester, 1973), 8-10, 43, 67, 94. 
Jean Rennie, and Arthur Harding all eventually tired of working in order to maintain their families. After years of inconsistent wage-earning or heavy drinking, they skipped out on their families altogether. A few men had never fulfilled their family obligations at all. Almost all of the illegitimate children among the autobiographers received no support of any kind from their fathers. Many of them had been placed with grandparents or in institutions shortly after their birth. ${ }^{59}$ The few that remained with (or later returned to) their mothers were raised without any contact with their fathers or financial support from them. ${ }^{60}$

Others had no more than a hazy recollection of fathers who had drifted away in the early years of their life. Guy Aldred's father, for example, had never "discharged his family responsibilities" and "took no interest," either in Guy's mother's welfare or his son's. His parents had only just managed to legitimize his birth - they tied the knot seven and a half weeks before he was born. But they had never set up home together, and Mr. Aldred had wandered completely out of Guy's life before he was six. ${ }^{61}$ Edward Brown's parents had separated so early in his life that he had no real recollection of his father. ${ }^{62}$ James Royce's father was "just a shadow sort of father." Royce could remember two brief interludes when his father had lived with them, one when he was about seven and another when he was about twelve. On the second occasion, Mr. Royce stole a pair of secondhand boots for his son and spent a few days wandering north London with him in an attempt to raise some money selling watercress before he took off again, never to return. Looking back, Royce dismissed the man's significance: "He didn't count." less common than fathers unable or unwilling to provide for their families, but it was not exactly rare. In all, forty-eight or 10 percent of the autobiographers reported a living but absent father. A number of points are worth underlining: in the fluid and anonymous society of the Victorian city, it was extremely easy for a man to leave his family; separations were decided by men, not women; and a father's desertion always signaled the end of his breadwinning for the family.

As must already be clear, the ineffective male breadwinner is not a negligible historical figure. The collection includes men who were unable to find steady work or too ill to perform it, as well as a large cast of characters who chose leisure over labor, who spent their earnings on their own private pleasures, who drank away their wages, and who, if it all became too much, walked away from their family altogether. But it is not simply because the stories are colorful that they belong to these accounts. It is also because they are so numerous. Indeed, ineffective fathers are only

\footnotetext{
59 See also Henry Morton Stanley, The Autobiography of Sir Henry Morton Stanley, ed. Dorothy Stanley (Boston, 1909); Emma Smith, A Cornish Waif's Story: An Autobiography (London, 1956); Pearl R. Wallis, "Down Memory Lane by Margaret Fowler," Surrey History Centre, Woking, 1674/10; H. J. Harris, "Autobiographical Letters, 1978-1984," BAWCA, ref. no. 2:363; Edward Balne, "Autobiography of an Ex-Workhouse and Poor Law School Boy," BAWCA, ref. no. 1:37.

${ }^{60}$ For example, Allan K. Taylor, From a Glasgow Slum to Fleet Street (London, 1949); Neville Cardus, Autobiography (London, 1947); Aubrey S. Darby, A View from the Alley, ed. J. G. Dony (Luton, 1974); Zoe Fairhurst, "Our Zoe of Gilling West: Her Life Story," Crosby Library Information Service, Waterloo, 920.7 FAI; Catherine Cookson, Our Kate: An Autobiographical Memoir (London, 1969).

${ }^{61}$ Guy Aldred, No Traitor's Gait! The Autobiography of Guy A. Aldred, 3 vols. (Glasgow, 1955-63), 1:910. See also Narrow Waters: The First Volume of the Life and Thoughts of a Common Man (London, 1935).

${ }^{62}$ Edward Brown, "Untitled," BAWCA, ref. no. 1:93.

${ }^{63}$ James Royce, I Stand Nude (London, 1937), 9, 41-47.
} 
a little less numerous among the autobiographers than those who were hardworking and steadfast. As noted above, 37 percent of the fathers described in the autobiographies were good providers. Many others who were not, whether through ill-health, unemployment, desertion, laziness, drunkenness, or any other cause-in all, a further 215 , a number very close to the 211 who were described as good providers by their children.

It is striking how clearly the contours of male provision for their families emerge in the majority of autobiographies once the question has been identified. The manner in which a man provided for his family was of critical importance to a writer's early experiences, and it was very difficult for a father to be both a good provider and a bad provider at the same time. Thus the majority of accounts slip easily into one category or the other. Around a quarter of them, however, do not. Most of these autobiographers either did not write about their fathers or skirted the issue of how effective their provision had been; the remaining few wrote about their fathers in inconsistent or contradictory terms, making simple categorizations impossible. Even if we were to conclude that all of this group of writers in fact had fathers who were good breadwinners-and there are no real grounds for this assumption, given that autobiographers had a clear and accessible vocabulary with which to write about fathers who were good providers-we are still left with a substantial proportion, 37 percent of all writers, raised in a home without the benefit of a full breadwinner's income. Indeed, the limitations of the breadwinning model go considerably further than this. My discussion has been confined to those autobiographers who had living fathers, but of course this was an era of high mortality. Around 12 percent of all writers were removed from the sample at the outset, as they had lost their father before reaching the age of sixteen. Consequently, the absolute numbers of those living without an effective breadwinner during at least some part of their childhood was considerably higher. Taking the entire collection of 662 autobiographers, almost half had spent some part of their childhood living either with a father who was unable to provide effectively or with no father at all; the other half included those who experienced fathers who were good providers ( 32 percent of the total), and those who did not indicate either way ( 22 percent of the total).

Of course, this takes us some way from the discussion of fatherhood. Despite the very real consequences of male mortality for women and children, we cannot usefully interrogate the history of fatherhood through fathers who were dead. Yet the point serves to underscore the fact that some families were hit by forces beyond their control, raising the question of how significant such external forces were in causing the poor providing that I describe. There are, after all, two very different contexts for non-providing fathers: those unable to work through unemployment or ill-health, and those who could and usually did work, but who made decisions that effectively deprived children of the resources they needed. The evidence is bleak. The autobiographies illustrate that neither ill-health nor unavoidable unemployment was a significant cause of families lacking a viable breadwinner. Of the fathers who did not provide for their families for one reason or another, fewer than 10 percent did so because they were unable to find work or because they were physically incapable of undertaking it. Personal failings emerge as a vastly more significant factor: drunkenness, desertion, irregular working patterns, and a refusal to share earnings explains the other 90 percent. I return to this observation below and query whether it is accurate to categorize these as "personal failings." 
For the present, however, it is worth underscoring that the lapses in breadwinning uncovered go far beyond impersonal forces such as ill-health and unemployment and extend deeply into the social, cultural, and familial.

Dividing fathers into "good" and "bad" providers imposes a degree of simplification upon family lives that were often anything but simple. The ways in which men fathered varied widely, not only between the good and bad providers but also within each of these groups. No less importantly, overlying all questions of provision and family relationships is a multifaceted web of emotions with the potential to muddy an adult writer's later assessment. Poor providers could be still be companionate and loving. Following an accident, Amy Rose's father was unable to earn much, but he was the only one in a large family who treated her with kindness, and in her memory that counted for a lot. ${ }^{64}$ On the other hand, fathers who worked hard for their families were occasionally arrogant, overbearing, or violent. Albert Goodwin's father was a skilled pottery worker on a good wage and took on two additional part-time jobs to provide a decent home for his family, but he was "obnoxious" and "boastful" and never tired of reminding his children of all that he did for them. ${ }^{65}$ More occasionally, fathers could be both violent and poor providers and yet still be loved by their children. Septimus O'Reilly's father was as drunken, violent, and abusive as they come. His last attack on his wife was so brutal that when the children crept downstairs to investigate, they feared she was dead. But even this violent assault did little to dent O"Reilly's love for his father. In the family breakup that followed, Reilly departed with his father, later refusing to comment on the "rights and wrongs of the case" and declaring "a real love for my father." 66 Using life writing to decipher family relationships is complex, as the interplay of provision and emotions can unfold in unpredictable ways. Yet for all this, there was also clear and significant overlap between provision and emotion, with writers generally providing warm and positive assessments of fathers who had provided to the best of their ability for their families, and an unmistakable strand of hostility toward those who had not.

Furthermore, clearly something is to be gained by asking what men's behavior meant for the women and children they lived with as opposed to what it meant for men themselves. When Mr. Jasper stuffed his money into his sock, his behavior presumably had some meaning to him, and this raises the prospect of exploring the codes that may have been guiding him. But if we are to avoid descending into an ever more intricate account of the meaning of male behavior, we must surely do more with the feckless Mr. Jasper than seek to understand how his actions made sense to him. His story is important as it captures one version of the struggle for resources that was played out to various degrees in many, many households. Breadwinning mattered because it mediated a child's experience of the world in profound ways. Diet, schooling, housing, health, and life opportunities were all powerfully influenced by family income, and it is for this reason the extent to which men provided for their families merits investigation as a research question in its own right.

\footnotetext{
${ }^{64}$ Amy Grace Rose, "Volume of Reminiscences MS" (1945), Cambridge Record Office, P137/28/3.

${ }^{65}$ Albert Goodwin, "Life of a Potter," in Burnett, Destiny Obscure, 294, 296-97.

${ }^{66}$ Septimus O'Reilly, The Tiger of the Legion: Being the Life Story of "Tiger" OrReilly as Told to William J. Elliott (London, 1936), 26-30.
} 
In working systematically through a large collection of autobiographies, I established that failures of fatherhood were a depressing and burdensome reality in the lives of a substantial number of women and children. Before accepting this conclusion, however, it is worth thinking more carefully about the reliability of the witnesses - the autobiographical writers. The careful reading strategies that scholars have developed over the past four decades have taught us that autobiographies are not a straightforward window into the past; they have counseled against drawing simple links between unique experiences described in the autobiographies and the lives of the population at large. Those caveats lead to the heart of the historian's craftour endeavor to reconstruct past realities on the basis of documentary evidence that is always partial and incomplete-and the problem is certainly pertinent to my study, given that I am extrapolating from a small number of autobiographies to the population at large. The key problem is one of distortion. We can all agree that some fathers failed their families. The critical question is, how many? Is it possible that children with a father who failed to provide effectively for them were more likely to write their life story as adults than those who did not, thus leading to an overinflation of such experiences in the autobiographical literature? It is not immediately obvious why this might have been the case, but it is something that deserves to be considered.

On looking closely at the ways in which writers wrote about their fathers, this suggestion seems unlikely. The autobiographies considered here were emphatically not books about fathers or families. Our writers had a range of different motivations - to tell of success in the arts or in business, to describe a life devoted to service to politics or the church, or to share the details of an "ordinary" life with family members or a community history project. But no matter what the motivation, recollections of early family life usually formed a small element of a narrative constructed for a different purpose. Most writers told the story of their family and childhood in a few opening pages, at most an opening chapter or two. Some dispatched their early years in a matter of lines, and some wrote nothing at all. These autobiographies were written long before the rise of the so-called misery literature of the 1990s, with its penchant for exposing childhood trauma. The writers considered here had a range of different motivations for telling their stories, but sensationalism was not one of them. There is no reason to think that they systematically lied about their fathers, exaggerated their flaws, or made up stories that were not true. For most writers, fathers were an interesting, yet ultimately incidental, detail.

This is true even among those with a more exceptional story of neglect or abuse to tell. There are miserable childhoods in the autobiographical literature to rival the most dismal misery literature on today's bestseller lists, ${ }^{67}$ yet they were retold and packaged in very different ways. Jack Martin, for instance, had a tale of horrific violence and abuse that he and his family had suffered at the hands of his father, but that was not where his story began. Before writing about his childhood, he filled the first thirty pages of his book with the reminiscences of a local doctor. His section on childhood-"My fight for existence in a family of 19 children"-was just one of nineteen

\footnotetext{
${ }^{67}$ For examples of misery literature, see David J Pelzer, A Child Called It (Deerfield Beach, 1995); Frank McCourt, Angela's Ashes (London, 1996).
} 
chapters. The other eighteen made virtually no reference to his desperate childhood or its legacy in the rest of his life. Others spoke in guarded terms or broached the topic of their father relatively late in their narrative. Flora Thompson wrote her autobiography in the third person and changed all her family's names, yet despite these precautions she still hesitated to describe "Laura's" father, his drinking, and the impact that he had on her family-just a very brief note in the second volume of her trilogy. ${ }^{68}$ It was only in private correspondence discovered by her biographer, Margaret Lane, that Thompson revealed that her father was reserving a large chunk of his wages for himself and sometimes failed to bring home any wages. ${ }^{69}$

Some autobiographers did not write about their fathers at all. Usually, of course, we have no way of knowing what lay behind this silence, though occasionally other parts of the historical record contain some clues. Mary Luty was one of those who wrote nothing about her father. Her early memories, as she told them, were of living with her mother on her father's farm. Her father's absence from the scene was never noted or explained-it would be natural to assume he had died. ${ }^{70}$ But checking the census indicates that he was not dead. Luty's parents, John Luty and Martha Ramsbottom, married in 1884, but had separated by the census of 1891 . John Luty was employed as a cotton weaver and was still living in Calderdale, west Yorkshire, whereas his wife had returned to her father's farm with the two children, just as Mary Luty described in her autobiography. In the same year, John Luty spent two weeks in prison for being drunk and disorderly, ${ }^{71}$ which hints at why the relationship had broken down.

The chance survival of two versions of one man's story also hints at the struggle that some writers had to put their childhood experiences down in writing. Arthur Harding wrote his autobiography, "My Apprenticeship to Crime," in the late 1960s. In 1970, he sent a copy to his member of Parliament, Stan Newens, who two years later passed it on to the historian Raphael Samuel. It was eventually deposited at the Bishopsgate Institute in 1998, where it remains. ${ }^{72}$ Samuel was so fascinated by Harding's extraordinary account of life in the East End of London at the turn of the century that he made contact with Harding and spent several years interviewing him, publishing the interviews in 1981 as East End Underworld: Chapters in the Life of Arthur Harding. As a result, there are two versions of Harding's life: "My Apprenticeship," the written story that Harding conceived and created himself, and East End Underworld, the oral account that emerged thorough his dialogue with Samuel.

As was often the case, Harding could not write about his childhood without discussing how his father had performed as the breadwinning male head of household. Unfortunately for the young Harding, his father was among those who had been unable to provide for their family, with the inevitable consequence that Harding

${ }^{68}$ Flora Thompson, Lark Rise to Candleford (1939; repr. London, 1973), 262-63.

${ }^{69}$ Margaret Lane, ed., Flora Thompson: A Country Calendar and Other Writings (London, 1976), 3, 83.

${ }^{70}$ Mary Luty, Penniless Globe Trotter (Accrington, 1937).

${ }^{71}$ Census Returns of England and Wales, 1891 and 1901, West Yorkshire Archive Service, "Nominal Register Number 30, 1891-1892," C118/140. See also the unpublished version of Luty's autobiography, Mary Luty, "My Life Has Sparkled," Rawtenstall Local Studies Library, Rawtenstall, Yorkshire, LG3 LUTY, Mary/LUT.

${ }^{72}$ Arthur Harding, "My Apprenticeship to Crime," Bishopsgate Institute Library, London. 
spent his early years living in abject poverty. However, although Mr. Harding's breadwinning failings were revealed, Harding was quick to locate the blame for these failings away from his father. ${ }^{73}$ In the autobiography, Harding's father was a pitiful victim suffering from bad eyesight, and it was only "through failing sight [that he] could not keep us." ${ }^{74}$ His inadequate provision for his family was either because he was "unemployed" attempt at his life story, he thus attributes his father's failure to provide to unfortunate circumstances beyond his control rather than any personal faults.

In discussion with Samuel, however, Harding took a very different stance toward his father. He told Raphael Samuel that his father "used to knock my mother about," that he was "ignorant and brutal" and "a bully."77 At times he neither provided for nor lived with his family, and this was not because of the unemployment or bad eyesight mentioned in the autobiography: it was because he was a selfish man who "only lived for himself." 78 Long before his sight began to fail, he was "a loafer," "too lazy to earn a living," "just an encumbrance really."79 On reflection, Harding declared that his father "wasn't really an invalid" at all. ${ }^{80}$ Clearly, although he was willing to voice his criticisms of his father to Raphael Samuel in the 1970s, a decade earlier he had not viewed his autobiography as a place to air such thoughts. He had simply left any unflattering details out. In a collection of over five hundred autobiographies, it is unlikely that Harding was the only author to make that choice.

Some writers concealed family problems, but as must be clear from the numerous examples presented, many did not. Yet even where writers did tell freely of their father's failings, it was not uncommon to find them simultaneously trying to excuse or exonerate their fathers, or at least chastise themselves for having raised the matter at all. "I don't want to blacken his character," wrote John Bennett, after sharing the details of his father's heavy drinking and "poor treatment" of his mother. ${ }^{81}$ "I hope I haven't given too biased an account," apologized Daisy Cowper after confessing that she had felt glad when she learned of her father's death. ${ }^{82}$ "It's a wrong thing for me to be telling you stories like this about my father. . . he had his kind moments I suppose," admitted Evan Rogers, before going on to say that those moments had been "very few, very few," and in fact he couldn't remember any. ${ }^{83}$ Writers frequently aired the unsavory details of their father's bad behavior, but they were not doing so in order to regale their reader with sensationalist and sordid tales. Bennett, Cowper, Rogers, and the many others looked at here wrote about their fathers because there was no way of providing an account of their early years without reference to this vital family member. And once they started writing,

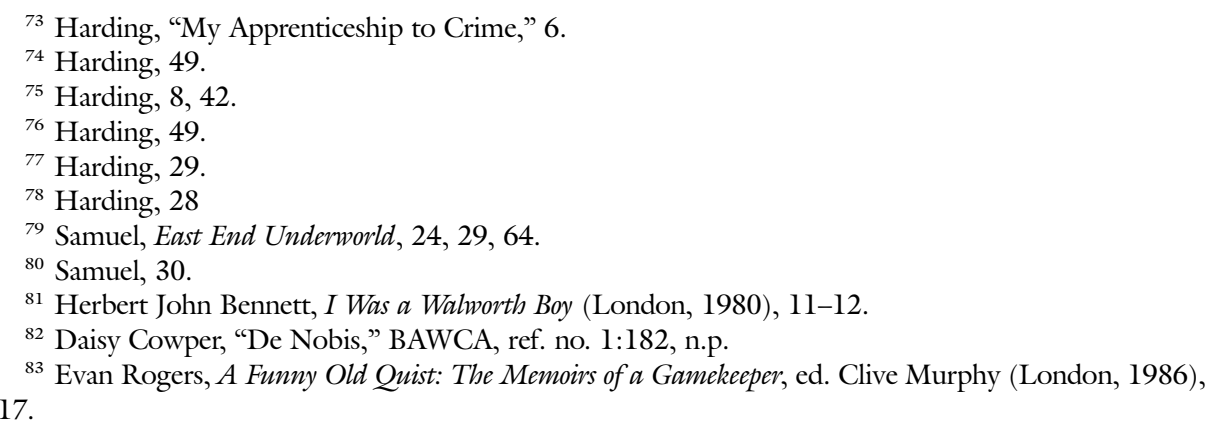


their father's failings took shape. They could not do otherwise, as the consequences of these failings had been so severe.

The match between the autobiographies of the few and lived experience of the many is of course ultimately unknowable, but there are no good grounds for suggesting that negative experiences are unduly exaggerated in the autobiographical literature. Learning that many, many children in Victorian Britain went without hot food and warm clothes not owing to the faceless force of poverty but because their fathers did not make the effort or sacrifice necessary to provide them makes for uncomfortable reading. Yet this message is clearly communicated in one autobiography after another, and when one considers the autobiographies collectively, it is clear that these are not unfortunate but isolated examples. They were part of the fabric of family life, part of the fabric of British society. And more generally, this evidence suggests a different agenda for research on life writing. If the families described in the autobiographies are neither atypical nor unrepresentative of the working classes more broadly, there are no grounds for maintaining that these records contain particular but not general truths. Quite the contrary: instead there is the possibility of a powerful new research agenda that seeks to use this material to better understand the changing social world.

\section{III}

The evidence from the autobiographies is clear: although the breadwinning family model worked well in some households, it manifested serious failings in others. Why might this have been? Why was the breadwinning family so prone to failure? Were there particular contexts, occupations, or regions in which it functioned well and others in which it did not? The detailed accounts of family life that autobiographers tend to provide are useful for delving into such questions.

Breadwinning failures were common among autobiographers' families, yet there was one small subset of writers for whom the breadwinning family model worked consistently well: those living on the land. Among the 577 writers with living fathers, nearly 140 individuals were raised in families living in agricultural villages, and of these, just fourteen had fathers who were unreliable providers. As noted above, 37 percent of writers reported a father who failed to provide effectively, but the figure for those raised in the countryside was much lower-just 10 percent. (The corollary of this, of course, was that the breadwinner model also functioned less well among urban communities than the average figure suggests: more than 45 percent of the writers raised in towns and cities offered evidence that their father had not provided effectively for the family.) Furthermore, within the rural context, agricultural laborers were the most reliable providers, while fathers pursing a more urban or skilled occupation were the least. Ten of the rural men who did not provide adequately for their families were agricultural laborers, but on considering these cases, it becomes clear that most of the men were in this position through reasons beyond their control. Three were invalids, which compromised their ability to work. ${ }^{84} \mathrm{~A}$ further three, all raising their families in the early part of the

\footnotetext{
${ }^{84}$ Mrs. Burrows, "A Childhood in the Fens about 1850-1860," in Life as We Have Known It, by Co-operative Working Women, ed. Margaret Llewelyn Davies (London, 1931), 109-14; Tom Tremewan, Cornish
} 
Victorian period, were suffering from adverse economic forces beyond their control - chronically low wages, short stints of unemployment, or high food prices. ${ }^{85}$ This leaves just four farmworkers who were able to provide for their family but did not do so reliably; three were spending money on drink, and the fourth was withholding money from his wife as a form of control. ${ }^{86}$ The other four poor providers were not in fact involved in agricultural labor. One was a higler (peddler), ${ }^{87}$ one ran a basket-weaving business, ${ }^{88}$ one was a stonemason, ${ }^{89}$ and the other was a journeyman bricklayer. ${ }^{90}$ All four were effectively self-employed tradesmen who happened to live in a village rather than a town.

There were, then, very few cases of fathers failing to provide for their families among those living in small, rural villages and dependent upon farming for their livelihood. As such, these families form a distinct social group whose experiences followed a markedly different trajectory from those living in urban and industrial areas, who were bound much more closely to the forces of social and economic modernization. This finding is highly suggestive and merits further analysis.

One can pursue this thread further by looking at writers who were born in the pre-1840 period. In addition to the 662 autobiographies that cover the Victorian period, there are more than 250 written by authors born before 1840, which raises the prospect of exploring the extent to which the quality of paternal provision was changing over time. Although comparisons become less secure as one moves back chronologically, it is clear that the same pattern holds for the pre-1840 period. Over sixty of the autobiographers born before 1840 were raised in agricultural communities, and of these, thirty-five had living fathers employed in agriculture. Here again, the number of those failing to provide for their families was small: just three. One was an elderly father unable to work owing to ill-health. ${ }^{91}$ The other two men were affected by low wages and unemployment. ${ }^{92}$ A further

Youth: Memories of a Perran Boy (1895-1910) (Truro, 1968), 14-15; Amy Grace Rose, untitled volume of reminiscences, Cambridgeshire Record Office, Cambridge, MS (1945), P137/28/3, 1, 4.

${ }^{85}$ Isaac Anderson, The Life History of Isaac Anderson: A Member of the Peculiar People (n.p, 1896), 6-7; George Edwards, From Crow-Scaring to Westminster: An Autobiography (1922?; repr. Dereham, 2008); Robert Crane, "An Old Man's Memories," Cambridgeshire Record Office, 231/Z65.

${ }^{86}$ Joy Lakeman, ed., Them Days: Devon Life of the 1890s-1920s, from the Memories of Joan Bellan (Padstow, 1982), 60-62; Margery Johnstone, "A Real Good Life Growing Up in the South East Midlands: The Life of Margery 'Mum' Johnstone in Her Own Words,” Bedfordshire Local Studies Library, Bedford, Central Library, Autobiography or memoir, B/JOH, 7; H. F. Smith, "The Life Story of Henry Frederick Smith," 134M96/A2; Henry Smith, "Autobiography," Hampshire Archives and Local Studies, Winchester, p. 7; Oakley, "Autobiography of Elizabeth Oakley," 130-31.

${ }^{87}$ Sybil Marshall, ed., Fenland Chronicle: Recollections of William Henry and Kate Mary Edwards (Cambridge, 1967).

${ }^{88}$ May Wasson, "Memories of Ninety Years," Bexley Local Studies and Archives Centre, Bexleyheath, ref. no. 920 .

89 Thompson, Lark Rise, 262-63.

${ }^{90}$ William Miles, An Autobiography: From Pit Bank to Balliol College: A Mineworker Became a Labour Election Agent for 20 Years (privately published, 1972).

91 "A Norfolk Labourer's Wife," Eastern Counties Magazine, 1901-1902, vols. 1-2, reprinted in E. A. Goodwyn and J. C. Baxter, eds., East Anglian Reminiscences (Ipswich, 1976), 24-29, at 28.

92 [Bill H.], "Autobiography of a Navvy" Macmillan's Magazine, no. 5, 1861-62: 140-51; extracts reprinted in Burnett, Useful Toil, 55-64; James Nye, A Small Account of My Travels through the Wilderness, ed. Vic Gammon (Brighton, [1982]), 11-12. 
five rural households lacked a reliable breadwinner, but in each of these cases the father worked in a trade rather than agriculture. ${ }^{93}$

It is important to underscore the significance of this finding. Agricultural wages were low, so many of the families in rural areas were, in absolute terms, poor. But throughout the eighteenth century and right down to the eve of 1914, so long as a father who worked in agriculture remained in good health, he was highly likely to both work regularly and turn over the great majority of his earnings to his wife. Time and again, the autobiographies reveal that the equilibrium in their families was destroyed by fathers who failed to provide adequately for them, yet one occupational group appears to be almost unaffected by this problem. It is therefore important to ask what was distinctive about rural life that served to funnel male earnings so effectively into the common family fund.

Several different forces, of course, were at work. For example, the choice to trade labor for leisure was simply not available to men who worked on the land. Most agricultural laborers were tied into yearlong contracts, and work was in any case too scarce to risk losing a job for failing to turn up when expected, which encouraged men to toil dutifully for their employers. But it was not simply that farmworkers worked regularly. It is also highly significant that they shared their wages with their wives, and part of the reason they did so was precisely because wages were so low. Several rural autobiographers noted that their family's limited means had deprived fathers of the freedom to spend money on themselves. As one autobiographer raised in a poor agricultural family in rural Scotland explained, his father "could not afford to be other than an abstainer." A few pennies worth of snuff was his only occasional luxury. ${ }^{94}$ William Arnold's father, a poor village shoemaker, hardly drank at all: he was "too poor" to do so. ${ }^{95}$ Waged work might earn a farmworker an entitlement to a bigger share of the household's resources, but there was nothing left over for personal spending outside the home.

Low wages did not simply rule out the possibility of men keeping and spending money on themselves: it also meant that men had no real choice but to hand their wages to their wife for housekeeping. Agricultural wages were never high enough to permit a man to purchase the kind of services that his wife supplied-provision of meals and clothing-on the open market. A man's basic human needs of food, clothing, and warmth could only be fulfilled through the unpaid services of family members. There was thus some equivalence in the value of waged work and unpaid domestic work, creating a high degree of codependency between husband and wife.

\footnotetext{
${ }^{93}$ John Gibbs, The Life and Experience of and Some Traces of the Lord's Gracious Dealings towards the Author John Gibbs (Lewes, 1827); William Gifford, Memoir of William Gifford, Written by Himself (London, 1827); Arthur Walter Slater, "Autobiographical Memoir of Joseph Jewell, 1763-1846," Camden Fourth Series, no. 1 (1964): 113-61; John Buckley, A Village Politician: The Life-Story of John Buckley, ed. J. C. Buckmaster (London, 1897); George Mitchell, "Autobiography and Reminiscences of George Mitchell, 'One from the Plough,"' in The Skeleton at the Plough, or, the Poor Farm Labourers of the West, ed. Stephen Price (London, 1875), 95-120. It is also interesting to note that four of these households were not conventional two-parent families, as in each case the mother had passed away.

94 "Autobiography of an Ordinary Man: With Odds and Ends to Match," British Library, General Reference Collection, 10827.cc.20, p. 6.

${ }^{95}$ James William Arnold, Recollections of William Arnold, ed. Keith Brooker (Northampton, 2014$), 107$.
} 
In addition, a host of forces outside the home reduced the scope for men to spend their earnings on themselves rather than their families. Small villages offered few opportunities for spending money. Rosina Harrison's father liked a glass of ale, but as there was no pub in the village, getting it meant a three-mile walk. ${ }^{96}$ Arthur Rowse's father went to market every Friday night, and that was the only time he was able to buy himself a drink-a "pint of bitter and two-pennorth of rum." There were no pubs in his village and "no liquor was allowed inside our home by my mother." 97 Of course, many larger villages had pubs, but powerful social pressures inhibited men from spending too much of their money there. In Arthur Rowse's village, "the farm gave employment to half the village in one capacity or another-hinds, labourers, stable-boys, maidservants." 98 And a landowning family that spent large sums on male wages did not also expect to see the money it paid into the rates being used to support the wives and children of men in its employ.

There were manifold differences between a small agricultural community and a larger urban or industrial settlement. But the foundation upon which all else rested was higher male wages, which placed hitherto unknown levels of choice and power in the hands of the men who earned them. As male wages moved away from subsistence levels, the absolute necessity for all individuals in the family to pool their resources and labor for the common good broke down, creating a new situation in which men could maintain a reasonable living standard by depositing only a part of their resources with their families, or even living away from them altogether. As male wages increased, the equivalence between a man's waged work and his wife's unpaid domestic work was disrupted, and the codependency between marriage partners was lost.

The precise effects of higher male wages on family dynamics played out in a number of different ways. Some men took advantage of higher earnings in order to trade work for leisure. Pat O'Mara's father was an alcoholic and a domestic abuser-one of a select group of deeply unpleasant fathers described within the autobiographical literature. He was imprisoned on a number of occasions for his brutal attacks on O'Mara's mother-no mean achievement, given that the policemen who were repeatedly called to the scene were entirely "unappreciative of my mother's dilemma [and] had contempt for her." 99 He was also a Liverpool dock laborer, where the day-rate of five shillings was considerably higher than the wages in agriculture. ${ }^{100}$ This did not translate into a higher standard of living for his family. As O'Mara explained, his father lived "the usual life of a dock laborer, seeking work when he liked and chucking it in when he liked."101 As a rule, he never worked more than a couple of days a week, enough to "ensure the rent and enough to get the barest necessities of living."102 The rest of the week he spent in the pub. The men who did not work regularly for their families were either concentrated in a small number of trades — mining, quarrying, and dock work — or working

\footnotetext{
${ }^{6}$ Rosina Harrison, Rose: My Life in Service (London, 1975), 13.

${ }_{97}$ A. L. Rowse, A Cornish Childhood: Autobiography of a Cornishman (1949; repr., London, 1956), 12.

98 Rowse, Cornish Childhood, 21.

${ }^{99}$ Pat O'Mara, The Autobiography of a Liverpool Irish Slummy (1934; repr., Liverpool, 2009), 52.

${ }^{100}$ O’Mara, Autobiography of a Liverpool Irish Slummy, 31.

101 O'Mara, 36.

102 O'Mara, 36-37.
} 
as general laborers in the nation's largest cities-London, Liverpool, and Birmingham. In all of these contexts, men were hired and paid by the day, and the ease of obtaining employment and the high wages they could earn permitted them to live a lifestyle of irregular labor unavailable to those working in most other sectors of the labor market. It is also noticeable that most of these men worked just enough to keep their families at subsistence level and out of the workhouse-as O'Mara observed, his father provided "the barest necessities of living." In some respects, Mr. O'Mara adhered to an older ideal of maintaining a family at the lowest acceptable level, which was all agricultural workers had traditionally been able to manage owing to their low wages. His additional earnings were used to free him from the drudgery of working a seventy-hour week rather than raising his family's living standards.

Some men were more likely to take advantage of better pay in order to earn a higher income than to reduce their hours of work. Yet even when men followed the path of steady labor, clearly not all believed that earnings above the family's subsistence needs belonged to the common family fund rather than to the wage earner. This belief lay at the root of a pattern of behavior repeatedly seen in the autobiographies, in which men deposited a part of their earnings with their wives for the family's upkeep and kept a part for their own private pleasures. As with the fathers who worked irregularly, these fathers provided for their family's basic needs; it was the ownership of the additional income that was contested.

Towns and cities not only provided higher male earnings but were also far more complex societies that enabled men to find substitutes for the things that traditionally were only provided in the home. Foremost among these was hot, cooked food. In the city now it was for sale, and even a humble workman had the means to purchase it. Arthur Harding and his family lived in the London's East End in the 1880s and 1890s, and his autobiography captures the dizzying array of venues selling foodstuffs: fish and chip shops; coffee shops selling tea and bread or a meal of meat, two vegetables and a piece of jam tart; fish shops selling bloaters, smoked haddocks, kippers, herrings, mackerel, and eels; pork butchers where you could buy "very good cooked food at very cheap prices"; cake shops that sold large bags of broken biscuits for a halfpenny; pudding shops selling hot pies, jam roly-poly, and beef soup; and German pork butchers selling faggots that could be eaten hot or cold. ${ }^{103} \mathrm{Mr}$. Harding's access to a range of hot, prepared food weakened his dependency upon the home and his wife's cooking.

It did not help, of course, that one of the most attractive and accessible ways to spend income was on alcohol, a substance with mind-altering and addictive qualities. ${ }^{104}$ It would be hard to overemphasize the role that alcohol played in draining resources from working-class homes. Indeed, heavy drinking was the single greatest cause of money hemorrhaging from family budgets. It was mentioned by eightyeight writers, or 15 percent of the writers with a memory of a living father, and almost half of all the households in which a father was failing to provide adequately for his family. In each of these cases, the father was drinking so heavily that his offspring considered it a drain on the family finances; in some cases the problem was so

${ }^{103}$ Samuel, East End Underworld, 5-8, 10, 26-29.

${ }^{104}$ See, more generally, James Nicholls, The Politics of Alcohol: A History of the Drink Question in England (Manchester, 2009); John Burnett, Liquid Pleasures: A Social History of Drinks in Modern Britain (London, 1999). 
bad that it was also affecting the man's ability to hold down a job and earn a steady wage. ${ }^{105}$

The culture of heavy drinking in the urban working classes was something that Victorian commentators frequently criticized, and historians have rightly been circumspect about repeating or endorsing those censorious attitudes. Yet much as we might want to distance ourselves from middle-class prejudices about working-class lives, it is difficult to escape the conclusion that drinking was indeed a problem. It was also overwhelmingly an urban phenomenon. Just 5 percent of rural autobiographers described a father who was drinking to excess, whereas more than 25 percent of urban autobiographers did. ${ }^{106}$ If one adds to this all those who recalled excessive drinking by mothers, stepparents, and other caregivers, around one-third of all the urban writers had firsthand experience of problem drinking. Rather than denying this reality, the question to ask is "Why?"

From the autobiographers' perspective, drinking was a personal failing, and collectively the writers heaped considerable scorn upon fathers who spent their earnings on drink rather than their families. But looking over hundreds of autobiographies and seeing so many fathers failing in the same ways again and again, I had to question whether drinking was a structural problem with roots outside the family rather than a personal failing. Albert Jasper was characteristically contemptuous of his father for drinking away his earnings and leaving the family trapped in poverty. He did not neglect to mention the time when his father came home drunk and passed out in a pool of his own excrement in the scullery. ${ }^{107}$ But it is also hard to imagine that Mr. Jasper, in the grip of a serious alcohol addiction and reviled by his family, was living a good life. In truth, alcohol is a harmful substance, and at some point a drinking addiction caused considerable suffering not only for families but also for the drinkers themselves.

Of course, to some degree, the rising level of drinking was a straightforward result of the upward trend in male wages: higher earnings allowed men to purchase greater quantities of alcohol than ever before. But higher incomes do not inevitably lead to more drinking. Drinking can also be a response to a specific situation, and it is possible that changes in the conditions of men's working and home lives also played a part. The elevation of male labor as a marker of masculinity severed men from the comforts of home and thrust them into the masculine, alcohol-drenched world of the pub. We can imagine men turning away from the home as the source of human company and personal identity and searching for these things in the public world of pubs and clubs instead. Joseph Stamper observed that each of the many pubs he used to visit with his father catered to its own clientele. Some were small, cozy, and inward looking. Others looked outwards, providing rooms and facilities

${ }^{105}$ Heavy drinking was also mentioned (though less frequently) with reference to mothers, stepparents, and other caregivers and the autobiographical writers themselves, bringing the total of writers mentioning harmful drinking to nearly 20 percent.

106 The rural autobiographers with fathers drinking were Kate Edwards, in Marshall, Fenland Chronicle; Johnstone, "A Real Good Life Growing Up in the South East Midlands; Miles, Autobiography: From Pit Bank to Balliol College; Henry Smith, Autobiography; Thompson, Lark Rise. Drinking was also suspected in the case of Charles Hansford: Charles Lewis, "Memoirs of a Bricklayer: The Life of Charles Lewis Hansford," uncatalogued, BAWCA.

107 Jasper, Hoxton Childhood, 83. 
for their drinkers-debating clubs, literary societies, libraries, "hot-pot suppers," sing-songs, and "mass merriment." 108 A little spare change was the ticket to pursuing such things as male friendships, leisure, and political engagement-all centered on the pub. John Allaway noticed that his father had been able to buy "personal popularity" by spending on beer and cigarettes for men at the public house. ${ }^{109}$ Alehouses promised warmth and friendship to men who might struggle to find these anywhere else. One author wrote that he fell into drinking himself because he enjoyed the alehouse as much as the drink-he "loved the company." 10

It is also noticeable that some of the male writers indicated that their own drinking became more problematic during times of crisis. The death of a baby, ${ }^{111}$ a cherished son, ${ }^{112}$ a child in a house fire: ${ }^{113}$ men gave these and similar events as the moment when their once-regulated drinking had begun to spiral out of control. Added to this is the fact that many forms of male labor were extremely demanding physically. One writer recalled how as an apprentice mason, he had attempted to "escape from [his] sense of depression and fatigue" by drinking whiskey. It "gave lightness and energy to both body and mind" and substituted for his usual state of "dullness and gloom, one of exhilaration and enjoyment." Whiskey, he concluded, was "simply happiness doled out by the glass." 114 Even in the absence of loss and trauma, men's daily lives could be exhausting and draining, and alcohol provided immediate relief from the day-today struggles of life. And seen from this perspective, the rise in heavy drinking appears less the personal failing of individual men and more a response to broader structural forces that served to weaken familial ties and destabilize the family unit.

Heavy drinking was only one response to the rapidly changing world. As long as male wages provided for no more than the meanest subsistence, all members of the family were tightly bound in a nexus of needs and responsibilities; but when men were able to earn something better than a subsistence wage they, and they alone, were freed from that nexus. The fathers who worked in the lowest-waged sectors of the economy may not have had large wages to share with their families, but they were often the most reliable providers. It was when wages were high in the urban and industrial sector that most of the problems of unreliable and heavy-drinking fathers occurred. And as these sectors grew steadily during the nineteenth century, so did the concomitant problems of absent fathers and ineffectual breadwinning.

More generally, the evidence presented here suggests a powerful new agenda for research on life writing. In the four decades since Burnett and his team established working-class autobiography as a major resource for researchers, the dominant

\footnotetext{
108 Joseph Stamper, So Long Ago . . . (London, 1960), 42, 106-7.

109 "John Allaway," 5-6.

${ }^{110}$ Charles Bent, Autobiography of Charles Bent, a Reclaimed Drunkard (Sheffield, 1866), 9.

111 The Life of James Mccurrey from 1801 to 1876, Containing Thirty-Nine Years' Experience as a Temperance Advocate and Missionary Collated from His Personal Narrative, Journals, etc. (London, 1876), 20. See also "Jacques,' Glimpses of a Chequered Life," Commonwealth, 8 November 1856, who took to "dramdrinking” when his wife died, leaving him with eight dependent children.

112 An Exposition of the Nefarious System of Making and Passing Spurious Coin [. . . Being the Confessions of a Coiner (Preston, n.d.), 6.

113 John Blow, Autobiography of John Blow (Leeds, 1870), 9.

${ }^{114}$ Hugh Miller, My Schools and Schoolmasters: or, the Story of my Education, 5th ed. (Edinburgh, 1856), 158-59. See also Arthur Horner, Incorrigible Rebel (London, 1960), 11.
} 
mode of enquiry has focused on the meaning of texts and the identity and experience of individual writers. In my making study of autobiographies, I sought to demonstrate that this kind of close reading can be supplemented with strategies to read widely across the collection and to search for connections between the writers as a group and the material world in which they lived. This is not to claim that the experiences of autobiographers-of family, work, political engagement, sex, leisure, or anything else-are always representative of those of the working classes or to argue for a simple equivalence between stories told by autobiographies and the world as at really was. The point rather is that the degree to which working-class writing can be deemed to be representative of working-class life is a historical problem that can and should be pursued. The difficulty in moving from the individual text to the lived world of the text's creator is no greater for autobiographical material than any other historical source, and seeking to better understand how personal narratives intersect with the material world can only enrich our understanding of the past. 